\title{
New record of Thalia cicar van Soest 1973 (Urochordata: Thaliacea) in the Equatorial Atlantic
}

\author{
Xiomara Franchesca García Díaz ${ }^{1,2}$, Lucia Maria de Oliveira Gusmão ${ }^{1}$ \& Sigrid Neumann-Leitão ${ }^{1}$ \\ ${ }^{1}$ Departamento de Oceanografia, Universidade Federal de Pernambuco - UFPE, \\ Av. Arquitetura, s/n, Cidade Universitaria, CEP 50670-901, Recife, PE, Brazil \\ ${ }^{2}$ Corresponding author: Xiomara Franchesca García Díaz, \\ e-mail: xiofra@yahoo.com, http://www.ufpe.br/docean
}

DIAZ, X.F.G., GUSMÃO, L.M.O. \& NEUMANN-LEITÃO, S. 2008. New record of Thalia cicar van Soest 1973 (Urochordata: Thaliacea) in the Equatorial Atlantic. Biota Neotrop. 8(3): http://www.biotaneotropica. org.br/v8n3/en/abstract?article+bn01108032008.

\begin{abstract}
Thalia cicar van Soest 1973 (Urochordata, Thaliacea) is considered a tropical-subtropical species, registered in the Atlantic Ocean at latitudes between 7-34 $\mathrm{S}$ and 6-32 $\mathrm{N}$. This work enlarges the occurrence of this species for Equatorial Atlantic waters. The specimens were found in a shelf break area of the Brazilian northeastern $\left(07^{\circ} 50^{\prime}-07^{\circ} 70^{\prime} \mathrm{S}\right.$ and $\left.34^{\circ} 23^{\prime} \mathrm{W}\right)$ during the expedition JOPS-II (Joint Oceanographic Projects II) in March 1995; and, in São Pedro e São Paulo arquipelago (0 55' N and 29² 20’ W) in May and June, 2005. These two areas are characterized by the presence of local upwelling that induces the ascent of bottom waters rich in nutrients, generating areas of larger productivity than the typically oligotrophic Equatorial Atlantic waters. The new occurrence of Thalia cicar reported in this work can be related to these more productive waters of Equatorial Atlantic. The species that is most commonly found in the Atlantic Ocean is $T$. democratica, and the lack of past records of T. cicar might have been caused by the taxonomic difficulties determining of the solitary and aggregate zooids of these two species. This work suggests the potential use of the ratios among tunic lengths as an additional character to differentiate $T$. cicar and $T$. democratica oozooids.
\end{abstract}

Keywords: salps, biogeography, Brazilian northeastern waters, São Pedro e São Paulo archipelago.

DIAZ, X.F.G., GUSMÃO, L.M.O. \& NEUMANN-LEITÃO, S. 2008. Novo registro de Thalia cicar van Soest 1973 (Urochordata: Thaliacea) no Atlântico Equatorial. Biota Neotrop. 8(3): http://www.biotaneotropica.org. br/v8n3/pt/abstract?article+bn01108032008.

Resumo: Thalia cicar van Soest 1973 (Urochordata, Thaliacea) é considerada uma espécie tropical-subtropical, registrada no oceano Atlântico desde 7 a $34^{\circ} \mathrm{S}$ e 6 a $32^{\circ} \mathrm{N}$. Este trabalho amplia a ocorrência desta espécie para águas do Atlântico equatorial. Os espécimes foram encontrados na plataforma continental do Nordeste brasileiro (07 50'-07 70' S e 34 23' W) durante a expedição JOPS-II (Joint Oceanographic Projects II) em março de 1995 e no arquipélago de São Pedro e São Paulo $\left(0^{\circ} 55^{\prime} \mathrm{N}\right.$ e $\left.29^{\circ} 20^{\prime} \mathrm{W}\right)$ em maio e junho de 2005 . Essas duas áreas se caracterizam pela presença de ressurgências locais que induzem a ascensão de nutrientes, gerando locais de alta produtividade, nas águas tipicamente oligotróficas do Atlântico equatorial. O registro de Thalia cicar nesses dois locais pode estar relacionado com essas águas de maior produtividade no Nordeste brasileiro. A espécie de Thalia comumente encontrada no oceano Atlântico é T. democratica e a ausência de registros passados de T. cicar pode decorrer das dificuldades taxonômicas em diferenciar os zoóides solitários e agregados dessas duas espécies. Este trabalho sugere a utilização da proporção entre os comprimentos das projeções da túnica como um caráter adicional para diferenciar os oozoóides destas duas espécies.

Palavras-chave: salpas, biogeografia, águas do nordeste brasileiro, arquipélago de São Pedro e São Paulo. 


\section{Introduction}

Salps (Class Thaliacea, Order Salpida) are the most common pelagic tunicates (Esnal 1979, Bone 1997). Salps can form massive aggregations of millions of individuals that may play a significant role in marine ecosystems and they exhibit some of the fastest growth rates of any multicellular organism (Esnal \& Daponte 1999). Salps are important contributors to the zooplanktonic community of the open ocean (Bone 1997). The greatest abundances are registered in waters of high latitudes (Casareto \& Nemoto 1986, Huntley et al. 1989) with a patchy distribution typical of most of the zooplanktonic groups. In the food chain, this group is considered as one of the principal picoplankton $(0.2-2 \mu \mathrm{m})$ and nanoplankton $(2-20 \mu \mathrm{m})$ consumers in oceanic waters (Kremer \& Madin 1992). Their feeding mechanism exhibits a high filtration rate that removes suspended particles by the pharyngeal water pumping (Madin 1974, Harbison \& Gilmer 1976). Salps play an important role in the transport of particles from the euphotic zone to deep waters, due to high defecation rates and fecal pellets with fast sinking rates, which are rich in non-digested materials (Miller \& Cosson 1997).

On average, salps are present at low abundances in relation to other zooplanktonic groups. Salps are very fragile and non-uniformly distributed in the water column. These features cause difficulties for quantitative sampling and organism collection in good conditions (Madin et al. 1996). For species determination the difficulties are mainly linked to the tunic fragility and the morphological similarities among species. Length and shape of the tunic projections are key characters for taxonomic identification of Thalia solitary forms (oozooids) (Esnal \& Daponte 1999). In the aggregate form (blastozooid) of this genus, the principal theory that explains the morphological characters similarity is the continuous gene flow among sympatric species (Borgelt 1968).

Thalia cicar holotype (a solitary zooid) and paratypes (nine solitary zooids and ten aggregate zooids) were recorded for the first time in 1970 at north Curaçao by van Soest (1973). Later, this species was registered by this same author in waters off Japan and South Africa (van Soest 1975). This author observed morphological variations in his collection and contributed to the differentiation of the species T. democratica (Forskål 1775), T. rhomboides (Quoy \& Gaimard 1824), T. orientalis Tokioka 1937 and T. longicauda (Quoy \& Gaimard 1824), and to the description of two new species: $T$. cicar van Soest 1973 and T. sibogae van Soest 1973.

Today seven species of Thalia are recognized, and four of these have been registered only to the South Atlantic (Esnal \& Daponte 1999). Among them, Thalia cicar is a tropical and subtropical species, with a latitudinal distribution in the Atlantic Ocean between 6 to $32^{\circ} \mathrm{N}$ and 7 to $34^{\circ} \mathrm{S}$. Absence of records of T. cicar in Equatorial Atlantic waters before the present work could be due to their patchy distribution and/or difficulties in their taxonomic identification. Also, the limited number of researches in this latitude might have contributed to this lack of information. The aim of this study was to enlarge the distribution of this species and suggest morphometrical characteristics that differentiate the oozooids of $T$. cicar and T. democratica, species commonly confused due their sympatric distribution and morphological similarities.

\section{Materials and Methods}

The zooplankton samples were collected during two oceanographic expeditions carried out in different periods, sampling areas and using different collection methods.

\section{Brazilian northeastern (Western Equatorial Atlantic)}

Samples from three stations located at coastal, shelf break and oceanic waters off the Brazilian northeastern (Western Equatorial
Atlantic) were analyzed (Figure 1). The collections were made aboard the German Research Vessel Victor Hensen during Leg 5 of the JOPS-II (Joint Oceanographic Projects II) expedition, in March 1995. The zooplankton was collected using a Bongo net $2 \mathrm{~m}$ long, $60 \mathrm{~cm}$ of mouth diameter, and $300 \mu \mathrm{m}$ mesh size, equipped with a flowmeter (Hydrobios) attached at the opening of the net. The Bongo net samples were taken as double oblique hauls from $200 \mathrm{~m}$ to surface, and the towing speed was about 3 knots. The samples were preserved in $4 \%$ buffered formalin/seawater solution.

\section{São Pedro e São Paulo archipelago (Central Equatorial Atlantic)}

The São Pedro e São Paulo archipelago (SPSPA) are a group of volcanic rocky islands formed near to São Paulo fracture of Mid-Atlantic ridge in Central Equatorial Atlantic $\left(0^{\circ} 55^{\prime} \mathrm{N}\right.$ and $29^{\circ} 20^{\prime} \mathrm{W}$ ) (Figure 1). Two sampling stations were established at SPSPA, one in the center of the bay and another on the west side of the archipelago (Figure 1). The hauls were made during five days between May $30^{\text {th }}$ and June $4^{\text {th }}$ of 2005 (Table 1), twice a day (morning and afternoon) at each station resulting in a set of 20 samples, only nine of them with $T$. cicar.

Sampling was done with a plankton net with $300 \mu \mathrm{m}$ mesh size with a flowmeter (Hydrobios) attached to the net mouth opening. Horizontal surface hauls were made with towing speed of 3 knots for 10 minutes. The fixation, identification and measures of the organisms were made in the same way as above.

\section{Taxonomy}

In the laboratory, all salps were picked out from the samples and identified using the Esnal and Daponte (1999) synopsis for the South Atlantic salps. Individuals were submerged during 24 hours in $2 \%$ Rose Bengal solution for a better observation of the taxonomic characters and later observed under a stereoscopic and a compound microscope. The oozooids measurements were made using a millimeter ocular: total length from the anterior to posterior part of the tunic excluding the posterior projections (1); tunic width (w); posterior projections length (pp) and lateral projections length (lp); superior (smp) and inferior (imp) mid-ventral projections length. For each oozooids the ratios between the tunic measurements $(1 / \mathrm{w}, 1 / \mathrm{pp}$, $\mathrm{pp} / \mathrm{lp}, 1 / \mathrm{lp}, \mathrm{smp} / \mathrm{imp}$ ) were calculated and compared with those of Thalia democratica. In the blastozooids, we measured the length (1) and tunic width $(\mathrm{w})$. The tunic measurements ratios were compared by $t$-student tests. This work includes images taken at Zooplankton Laboratory (Universidade Federal de Pernambuco — UFPE, Brazil) with digital camera.

\section{Results}

\section{Brazilian northeast (Western Equatorial Atlantic)}

Thalia cicar was found only in the samples taken from the region of the shelf break. This is the first record of this species from the northeastern Brazilian waters. The six registered individuals were oozooids. Three of them, presented only the tunic with stolon (without the internal organs). The length of the organisms were between 2.13 and $6.38 \mathrm{~mm}(\bar{\chi}=3.65, \mathrm{SD}= \pm 1.72, \mathrm{~N}=6)$ and their width between 1.28 and $3.72 \mathrm{~mm}(\bar{\chi}=1.92, \mathrm{SD}= \pm 0.93, \mathrm{~N}=6)$.

\section{São Pedro e São Paulo archipelago (SPSPA)}

In SPSPA, both oozooids and blastozooids of T. cicar were found, with the predominance of the aggregate form. The oozooids presented a length between 2.02 and $6.64 \mathrm{~mm}(\bar{\chi}=4.65, \mathrm{SD}= \pm 1.29, \mathrm{~N}=10)$ and width between 1.39 and $5 \mathrm{~mm}(\bar{\chi}=3.21, \mathrm{SD}= \pm 1.11, \mathrm{~N}=10)$. 


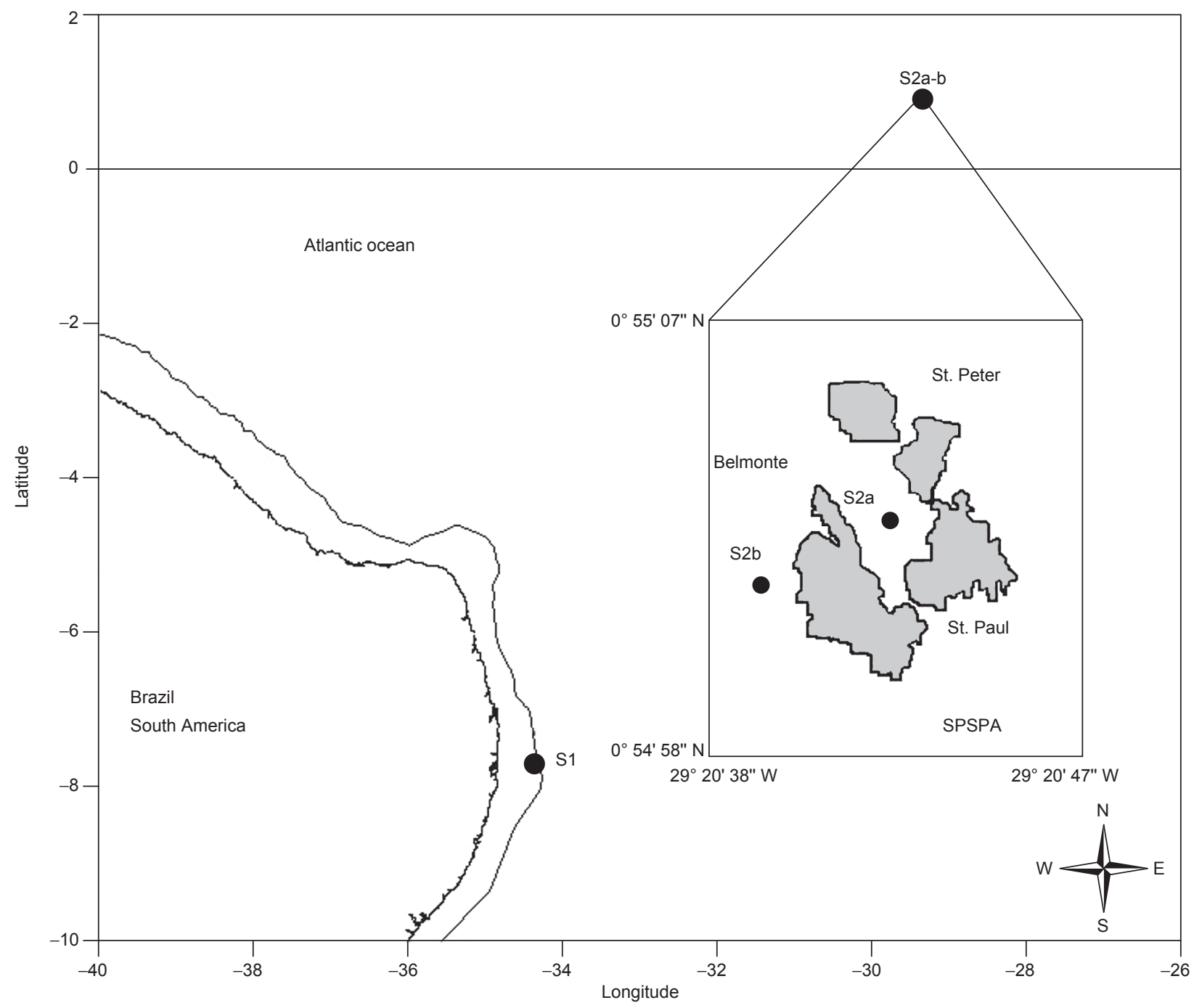

Figure 1. Sampling stations where Thalia cicar was found: $\mathrm{S} 1$ = Brazilian Northeast (Western Equatorial Atlantic) $\left(07^{\circ} 41^{\prime} \mathrm{S}\right.$ and $\left.34^{\circ} 23^{\prime} \mathrm{W}\right)$; $\mathrm{S} 2=\mathrm{São}$

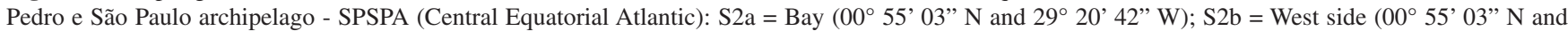
$\left.29^{\circ} 20^{\prime} 46^{\prime \prime} \mathrm{W}\right)$.

Figura 1. Estações de amostragem onde Thalia cicar foi registrada: S1 = Nordeste Brasileiro (Atlântico oeste equatorial) $\left(07^{\circ} 41^{\prime} \mathrm{S}\right.$ e $\left.34^{\circ} 23^{\prime} \mathrm{O}\right)$; S2 = Arquipélago de São Pedro e São Paulo - ASPSP (Atlântico central equatorial): S2a = Enseada (005 $55^{\prime} 03^{\prime \prime}$ N e 29²0’ 42” O); S2b = Lado oeste (00 55’03” N e $29^{\circ} 20^{\prime} 46^{\prime \prime}$ ) ).

Table 1. Collection data and coordinates of the sampling stations where Thalia cicar was found: (S1) Break shelf of Brazilian Northeast (Western Equatorial Atlantic), (S2a, S2b) São Pedro e São Paulo archipelago (Equatorial Atlantic).

Tabela 1. Dados de coleta e coordenadas das estações de amostragem onde Thalia cicar foi registrada: (S1) Quebra de plataforma no nordeste brasileiro (Atlântico oeste equatorial), (S2a, S2b) Arquipélago São Pedro e São Paulo (Atlântico equatorial).

\begin{tabular}{|c|c|c|c|c|c|c|}
\hline Station & Latitude & Longitude & Area & Local depth (m) & Date & Beginning time \\
\hline S1 & $07^{\circ} 41^{\prime} \mathrm{S}$ & $34^{\circ} 23^{\prime} \mathrm{W}$ & Break shelf & 600 & $02 / 03 / 95$ & 4:06 PM \\
\hline S2a & $00^{\circ} 55^{\prime} 03^{\prime \prime} \mathrm{N}$ & $29^{\circ} 20^{\prime} 42^{\prime \prime} \mathrm{W}$ & Oceanic-bay SPSPA & $7-20$ & 01/06/05 & 4:53 PM \\
\hline- & - & - & - & - & 02/06/05 & 7:00 AM \\
\hline- & - & - & - & - & 02/06/05 & 5:15 PM \\
\hline- & - & - & - & - & 03/06/05 & $5: 25 \mathrm{PM}$ \\
\hline- & - & - & - & - & 04/06/05 & 7:39 AM \\
\hline $\mathrm{S} 2 \mathrm{~b}$ & $00^{\circ} 55^{\prime} 03^{\prime \prime} \mathrm{N}$ & $29^{\circ} 20^{\prime} 46^{\prime \prime} \mathrm{W}$ & Oceanic-Outside SPSPA & $15-4.000$ & 01/06/05 & 8:08 AM \\
\hline- & - & - & - & - & 01/06/05 & 5:08 PM \\
\hline- & - & - & - & - & 02/06/05 & 7:32 AM \\
\hline & - & - & - & - & 02/06/05 & 5:30 PM \\
\hline
\end{tabular}


The blastozooids presented a length between 4.73 and $5.16 \mathrm{~mm}$ $(\bar{\chi}=4.89, \mathrm{SD}= \pm 0.23, \mathrm{~N}=3)$ and a width between 2.23 and $3.19 \mathrm{~mm}$ $(\bar{\chi}=2.78, \mathrm{SD}= \pm 0.49, \mathrm{~N}=3)$.

\section{Comparison between Thalia cicar and T. democratica}

In the haul carried out by the shelf break, oozooides of Thalia cicar and Thalia democratica co-occurred. In SPSPA both blastozooids and oozooids, were found. These two species are very similar morphologically (Figure 2), causing confusion in their taxonomic identification.

All oozooids of T. cicar and T. democratica exhibit differences in the length of the tunic projections and subsequent differences in the ratios between these projections. Significant differences between the two species in the majority of tunic measurements ratios (p-value $<0.05$ ) were found, as showed in the Table 2 . No differences between tunic length and posterior projection length ratio (1/pp) and superior and inferior mid-ventral projections length ratio (smp/imp) were observed. The $\mathrm{pp} / \mathrm{lp}$ ratio was smaller in $T$. cicar than in T. democratica. The posterior projection length was longer than the lateral projections in $T$. democratica (Table 2). The $1 / 1 p$, 1/smp, 1/imp ratios showed that the tunic length was longer than tunic projections in $T$. democratica (Table 2).

\section{Discussion}

Esnal \& Daponte (1999) reported a tropical-subtropical distributional pattern of $T$. cicar with latitudinal limits, being found between 20 and $35^{\circ}$ in the South Atlantic. In Brazilian coast, this species was registered to the South of the latitude $12^{\circ} \mathrm{S}$ in the states of Bahia, Espírito Santo and Rio de Janeiro (Bonecker \& Quintas 2006). Despite the low abundances in Southern Brazil, during the summer T. cicar seems to be favored by tropical waters (due the thermophile character of this species), as suggested by Amaral et al. (1997). Reports of T. cicar in the Atlantic Ocean are rare (Table 3). In the Gulf of Mexico, Yucatán Channel and Caribbean Sea, T. cicar was found predominantly with high frequency of occurrence (Esnal 1979) and with high abundances at the Dutch Antilles surroundings waters (van Soest 1973). In the Equatorial oceanic waters, this species was registered only from the mid Atlantic by van Soest (1973).

The waters of northeastern Brazil are characterized by low

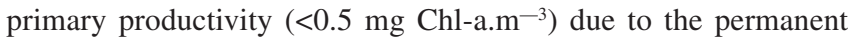
thermocline that inhibits the upward flow of nutrients (Medeiros et al. 1999, Neumann-Leitão et al. 1999). Higher productivities in the
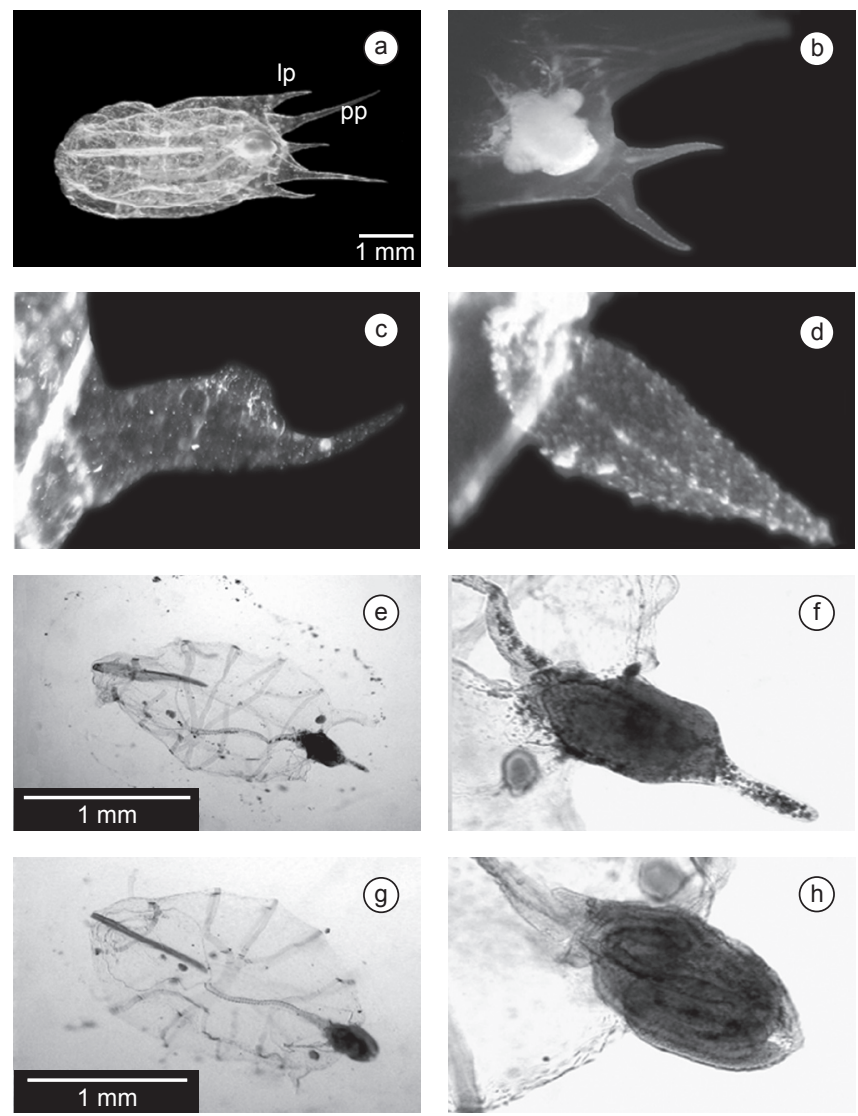

(h)

Figure 2. Morphological characteristics of Thalia cicar and T. democratica (individuals collected at SPSPA); a) T. cicar solitary form, ventral view (lp = lateral projections, $\mathrm{pp}=$ subsequent projections $)$; b) T. cicar solitary form, lateral view, mid-ventral projections; c) T. cicar, bifurcated atrial palp; d) T. democratica, simple atrial palp; e) T. democratica aggregate form, ventral view; f) T. democratica aggregate form, nucleus with projection; g) T. cicar aggregate form, ventral view and h) T. cicar aggregate form, nucleus without projection (Pictures: Sérgio Almeida).

Figura 2. Características morfológicas de Thalia cicar e T. democratica (Indivíduos coletados no ASPSP); a) Forma solitária de T. cicar, vista ventral $(1 \mathrm{p}=$ rojeções laterais, $\mathrm{pp}=$ projeções posteriores $)$; b) Forma solitária de $T$. icar, vista lateral, projeções médio-ventrais; c) T. cicar, palpo atrial bifurcado; d) T. democratica, palpo atrial simples; e) Forma agregada de $T$. democratica, vista ventral; f) Forma agregada de T. democratica, núcleo e projeção; g) Forma agregada de $T$. cicar, vista ventral e h) Forma agregada de T. cicar, núcleo sem projeção (Fotos: Sérgio Almeida).

Table 2. Differences between Thalia cicar and T. democratica based on the tunic ratios and their projections: tunic length (1), tunic width (w), posterior projections length (pp), lateral projections length (lp); superior mid-ventral projections length (smp) and inferior mid-ventral projections length (imp).

Tabela 2. Diferenças entre Thalia cicar e T. democratica baseadas nas proporções das medidas da testa e das suas projeções: comprimento da testa (1), largo da testa (w), comprimento das projeções posteriores (pp), comprimento das projeções laterais (lp); comprimento das projeções médio-ventrais superiores (smp) e comprimento das projeções médio-ventrais inferiores (imp).

\begin{tabular}{|c|c|c|c|c|c|c|}
\hline \multirow{2}{*}{ pp simp } & \multirow[t]{2}{*}{ Ratio } & \multicolumn{2}{|c|}{$\begin{array}{l}\text { Thalia cicar } \\
\qquad \mathrm{N}=\mathbf{1 0}\end{array}$} & \multicolumn{2}{|c|}{$\begin{array}{c}\text { Thalia democratica } \\
\qquad \mathrm{N}=7\end{array}$} & \multirow[t]{2}{*}{$\begin{array}{c}\text { p-value } \\
(t \text {-student test })\end{array}$} \\
\hline & & $\bar{\chi}$ & SD & $\bar{\chi}$ & SD & \\
\hline \multirow{5}{*}{1} & $1 / \mathrm{w}$ & 1.49 & \pm 0.21 & 1.79 & \pm 0.22 & 0.0152 \\
\hline & $1 / p p$ & 1.94 & \pm 0.71 & 1.60 & \pm 0.21 & 0.1837 \\
\hline & $\mathrm{pp} / \mathrm{lp}$ & 1.67 & \pm 0.52 & 4.56 & \pm 1.10 & 0.0002 \\
\hline & 1/lp & 3.02 & \pm 0.78 & 7.22 & \pm 1.60 & 0.0002 \\
\hline & smp/imp & 1.24 & \pm 0.50 & 1.57 & \pm 0.32 & 0.1181 \\
\hline \multirow[t]{2}{*}{ ozooid (dorsal view) } & $1 / \mathrm{smp}$ & 4.53 & \pm 0.74 & 11.08 & \pm 2.67 & 0.0005 \\
\hline & 1/imp & 5.45 & \pm 1.60 & 17.43 & \pm 5.61 & 0.0011 \\
\hline
\end{tabular}


Table 3. Records of Thalia cicar in the Atlantic Ocean ( $?=$ information not available).

Tabela 3. Registros de Thalia cicar no oceano Atlântico (? = informação não disponibilizada).

\begin{tabular}{|c|c|c|c|c|}
\hline Geographical area & Latitude & Longitude & Date & Reference \\
\hline Bermuda & $32^{\circ} \mathrm{N}$ & $65^{\circ} \mathrm{W}$ & $?$ & van Soest, 1973 \\
\hline Campeche Bay & $20-24^{\circ} \mathrm{N}$ & $90-96^{\circ} \mathrm{W}$ & $\begin{array}{c}\text { August } 1971 \\
\text { August and October } 1972 \\
\text { August } 1973\end{array}$ & Esnal, 1979 \\
\hline Florida East Coast & $24-28^{\circ} \mathrm{N}$ & $82-86^{\circ} \mathrm{W}$ & May 1974 & Esnal, 1979 \\
\hline Yucatan Channel & $20-24^{\circ} \mathrm{N}$ & $90-84^{\circ} \mathrm{W}$ & $\begin{array}{c}\text { August } 1971 \\
\text { October } 1972 \\
\text { February } 1973\end{array}$ & Esnal, 1979 \\
\hline Yucatan and Caiman & $16-22^{\circ} \mathrm{N}$ & $78-88^{\circ} \mathrm{W}$ & $\begin{array}{l}\text { August } 1971 \\
\text { October } 1972 \\
\text { March } 1973\end{array}$ & Esnal, 1979 \\
\hline Caribbean Sea and Dutch Antilles & $12-13^{\circ} \mathrm{N}$ & $68-70^{\circ} \mathrm{W}$ & February 1973 & Esnal, 1979 \\
\hline Curaçao, Aruba and Bonaire. Surinam Coast & $\begin{array}{l}10-11^{\circ} \mathrm{N} \\
06-08^{\circ} \mathrm{N}\end{array}$ & $\begin{array}{l}61-62^{\circ} \mathrm{W} \\
52-57^{\circ} \mathrm{W}\end{array}$ & $?$ & van Soest, 1973 \\
\hline Central South Atlantic & $07^{\circ} \mathrm{S}$ & $08^{\circ} \mathrm{W}$ & ? & van Soest, 1973 \\
\hline Bahia, Brazil to Tomé Cape-Davis Bank-Trinidad Island & $12-24^{\circ} \mathrm{S}$ & $42-28^{\circ} \mathrm{W}$ & ? & $\begin{array}{l}\text { Bonecker and } \\
\text { Quintas, } 2006\end{array}$ \\
\hline Southern Brazil & $\begin{array}{l}31^{\circ} 40^{\prime} \mathrm{S} \\
33^{\circ} 45^{\prime} \mathrm{S}\end{array}$ & & February 1990 & Amaral et al. 1997 \\
\hline
\end{tabular}

shelf break areas can be caused by topographic upwelling and trade winds, favoring nutrients and planktonic enrichment of the superficial layers (Fournier 1978, Pingree \& Mardell 1981, Mann \& Lazier 1991).

The tropical oceanic regions are usually oligotrophic with a minimum vertical flow of nutrients and low biological production (Longhurst \& Pauly 1987, Boltovskoy et al. 1999). However, areas with vertical mixtures caused by currents divergence, winds and oceanic currents interactions with the submarine relief, increase the biological production in regions as SPSPA (Travassos et al. 1999). The presence of $T$. cicar at the shelf break and/or oceanic islands, where the bottom topography favors local upwelling of deep waters, indicates the possible relationship between these organisms and some specific areas at Equatorial Atlantic Ocean with higher primary productivity.

The majority of salps are not able to modify their filtration rate in response to food concentration changes due to their feeding mechanism, thus the clogging of the filtration system can explain their absence in coastal waters rich in particulate matter (Deibel 1982, Harbison et al. 1986). Copepoda, the most abundant zooplanktonic group, feed on mixed diets of natural phytoplankton and microzooplankton (Turner 2004) but do not feed efficiently on particles smaller than $5 \mu \mathrm{m}$ (Nival \& Nival 1976), except the nauplii of various copepod species, which have been shown to feed upon bacterioplankton (Turner \& Tester 1992, Roff et al. 1995). The ability of tunicates to take up very small food particles $(<1 \mu \mathrm{m})$ may be an explanation for the great success in ultra-oligotrophic environments (Raymont 1983, Kremer \& Madin 1992, Acuña, 1999). However, Thalia species might have the capacity to adjust their mucus production or to change the water pumping rate in a high particle concentration (Madin 1995). For this reason, it is possible that the presence of T. cicar was independent of the suspended particle concentration and was favored by local areas with higher productivity than circundant waters. However, those mechanisms suggest circumstances under experimental laboratory evidences. Madin (1995) shows data based only on some morphological features of Thalia that occurs on coastal waters.
The morphological similarities between T. cicar and T. democratica and their sympatric distribution could be the main causes for the exclusive record of $T$. democratica in the equatorial Atlantic waters. Thalia democratica has a wide distribution and is the most abundant salp in the South Atlantic (Esnal \& Daponte 1999). It is necessary to identify some characteristics that facilitate the differentiation among Thalia species. A single example is the development of the blastogenic stolon and the position of the oozooids tunnel, characteristics that differentiate Thalia longicauda from other Thalia species (Daponte et al. 1996). The only species of the genus Thalia that has been reported in northeastern Brazilian waters was Thalia democratica, (Neumann-Leitão et al. 1999). The basic characteristic described by van Soest (1973) that differentiate the oozooids of the two species are the length of the posterior projections (long in T. democratica and short in $T$. cicar), the length of the lateral projections (small in $T$. democratica and long in T. cicar), the atrial palps (simple in T. democratica and bifurcate in T. cicar) (Figures $2 \mathrm{c}, \mathrm{d}$ ) and the length of the mid-ventral projections (small in $T$. democratica and large in T. cicar). The blastozooids differ by the absence of the nucleus projection in $T$. cicar (Figures $2 \mathrm{f}, \mathrm{h}$ ). The corporal structures ratios defined in this study were additional characters that can be used to differentiate these two species, beyond the taxonomical differences mentioned by van Soest (1973) and Esnal \& Daponte (1999).

This study extends the latitudinal distribution of $T$. cicar to the west and central Equatorial Atlantic Ocean, suggesting that the lack of records in the past in this area was due to difficulties in taxonomic identification, a non-uniform distribution (in patches) and/or by limited researches in these regions.

\section{Acknowledgements}

We are grateful to doctors Graciela Esnal and Maria Cristina Dapote, of the Evolution and Ecology Department of Buenos Aires's University (Argentina) by the confirmation of species. To Dr. C. H. Fernando, Department of Biology, University of Waterloo (Canada) for editing the text and the English language. To Sérgio Almeida for 
the photos. To Mônica Costa and Leandro Cabanez Ferreira for the manuscript suggestions.

\section{References}

ACUÑA, J.L. 1999. In situ ingestion rates of appendicularian tunicates in the Northeast Water Polynya (NE Greenland). Mar. Ecol. Prog. Ser. 186:149-160.

AMARAL, W.J.A., MONTÚ, M.A. \& GLOEDEN, I.M. 1997. Salpidae (Thaliacea) da plataforma continental do extremo sul do Brasil: Composição, distribuição e abundância (Verão de 1990). Rev. Atlântica (19):31-50.

BOLTOVSKOY, D., GIBBONS, M.J., HUTCHINGS, L. \& BINET, D. 1999. General biological features of the South Atlantic. In South Atlanctic Zooplankton (D. BOLTOVSKOY, ed.). Brackuys Publishers, Leiden, p. $1-42$.

BONE, Q. 1997. Biology of Pelagic Tunicates. Oxford University Press, New York.

BONECKER, S.L.C. \& QUINTAS, M.C.C. 2006. Salpidae. In Atlas de zooplâncton da região central da Zona Econômica Exclusiva brasileira (S.L.C. BONECKER, ed.). Museu Nacional, Rio de Janeiro, p. 203-213.

BORGELT, J.P. 1968. The subspecific differentiation of the salp Thalia democratica (Forskål, 1775) based on numerical taxonomical studies. Trans. Roy. Soc. S. Africa 38(1):45-64.

CASARETO, B. \& NEMOTO, E.T. 1986. Salps of the Southern Ocean (Australian sector) during the 1983-84 summer, with special reference to the species Salpa thompsoni, Foxton 1961. Mem. Nat. Inst. Polar Res. 7(40):21-239.

DAPONTE, M.C., CASTRO, R.J. \& ESNAL, G.B. 1996. An evaluation of the systematics of the genus Thalia (Thaliacea, Salpidae) based on new material from the EASTROPAC and MORRO expeditions. Contrib. Zool. 66(3):185-191.

DEIBEL, D. 1982. Laboratory-measured grazing and ingestion rates of the salp Thalia democratica Forskål, and the doliolid, Dolioleta gegenbauri Uljanin (Tunicata, Thaliacea). J. Plank. Res. 4(2):189-201.

ESNAL, G.B. 1979. Los Salpidos (Tunicata:Thaliacea) del Golfo de Mexico y Mar Caribe. Physis, Sección A, 38(94):59-66.

ESNAL, G.B. \& DAPONTE, M.C. 1999. Salpida. In South Atlanctic Zooplankton (D. BOLTOVSKOY, ed.). Brackuys Publishers, Leiden, p. 1423-1444.

FOURNIER, R.O. 1978. Biological aspects of the Nova Scotian shelfbreak fronts. In Oceanic fronts in coastal processes (M.J. BOWMAN \& W.E. ESAIAS, eds.). Springerg-Verlag, New York, p.69-77.

HARBISON, G.R. \& GILMER, R.W. 1976. The feeding rates of the pelagic tunicate Pegea confoederata and two others salps. Limnol. Oceanol. 4(21):517-529.

HARBISON, G.R., MCALISTER, V.L. \& GILMER, R.W. 1986. The response of the salp Pegea confoederata to high levels of particulate material: starvation in the midst of plenty. Limnol. Oceanol. 31(2):371-382.

HUNTLEY, M.E, SYKES, P.F. \& MARIN, V. 1989. Biometry and trophodynamics of Salpa thompsoni Foxton (Tunicata:Thaliacea) near the Antartic peninsula in Austral summer, 1983-1984. Polar Biol. 10(1):59-70.
KREMER, P. \& MADIN, P. 1992. Particle retention efficiency of salps. J. Plank. Res. 14(7):1009-1015.

LONGHURST, A.R. \& PAULY, D. 1987. Ecology of Tropical Oceans. Academic Pres Ins., San Diego.

MADIN, L.P. 1974. Field observations on the feeding behaviour of salps (Tunicata, Thaliacea). Mar. Biol. 25(2):142-147.

MADIN, L.P. 1995. Sensory ecology of salps (Tunicata, Thaliacea): more questions than answers. Mar. and Freshwater Beh. and Physiol. 26(2-4):175-195.

MADIN, L.P., KREMER, P. \& HACKER, S. 1996. Distribution and vertical migration of salps (Tunicata, Thaliacea) near Bermuda. J. Plank. Res. 18(5):747-755.

MANN, K.H. \& LAZIER, J.R.N. 1991. Dynamics of Marine Ecosystems. Biological-physical interactions in the Oceans. Blakwell Scientic Publishers, Oxford.

MEDEIROS, C., MACÊDO, S.J., FEITOSA, F.A.N. \& KOENING, M.L. 1999. Hydrography and phytoplankton biomass and abundance of North-East Brazilian waters. Arch. Fish. Mar. Res. 47(2-3):133-151.

MILLER, R.L. \& COSSON, J. 1997. Timing of sperm shedding and release of aggregates in the salp Thalia democratica (Urochordatha: Thaliacea). Mar. Biol. 129(4):607-614.

NEUMANN-LEITÃO, S., GUSMÃO, L.M.O., ALMEIDA E SILVA, T., NASCIMENTO-VIEIRA, D.A.N. \& SILVA, A.A.P. 1999. Mesozooplankton biomass and diversity in coastal and oceanic waters off North-Eastern Brazil. Arch. Fish. Mar. Res. 47(2-3):153-165.

NIVAL, P. \& NIVAL, S. 1976. Particle retation efficiencies of an herbivorous copepod, Acartia clausi (adult and copepodit stages): effects on grazing. Limnol. Oceanol. 21(1):24-38.

PINGREE, R.D. \& MARDELL, G.T. 1981. Slope turbulence, internal waves and phytoplankton growth in the Celtic Sea shelf-break. Phil. Trans. Roy. Soc. Lond., Londres, A (302):663-682.

RAYMONT, J.E.G. 1983. Plankton and productivity in the oceans. Zooplankton, 2. Pergamon Press, Oxford.

ROFF, J.C., TURNER, J.T., WEBBER, M.K. \& HOPCROFT, R.R. 1995. Bacterivory by tropical copepod nauplii: extent and possible significance. Aquat. Microb. Ecol. 9(2):165-175.

TRAVASSOS, P., HAZIN, F.H.V., ZAGAGLIA, J.R., ADVINCULA, R. \& SCHOBER, J. 1999. Termohaline structure around seamonts and islands off north-eastern Brazil. Arch. Fish. Mar. Res. 47(2-3):211-222.

TURNER, J.T. 2004. The importance of small planktonic copepods and their roles in pelagic marine food webs. Zool. Stud. 43(2):255-266.

TURNER J.T. \& P.A. TESTER. 1992. Zooplankton feeding ecology: bacterivory by metazoan microzooplankton. J. Exp. Mar. Biol. Ecol. 160(2):149-167.

VAN SOEST, R.W.M. 1975. Zoogeography and speciation in the Salpidae (Tunicata, Thaliacea). Beaufortia 23(307):181-215.

VAN SOEST, R.W.M. 1973. The genus Thalia Blumenbach, 1798 (Tunicata, Thaliacea), with descriptions of two new species. Beaufortia, 20(271):193-212. 